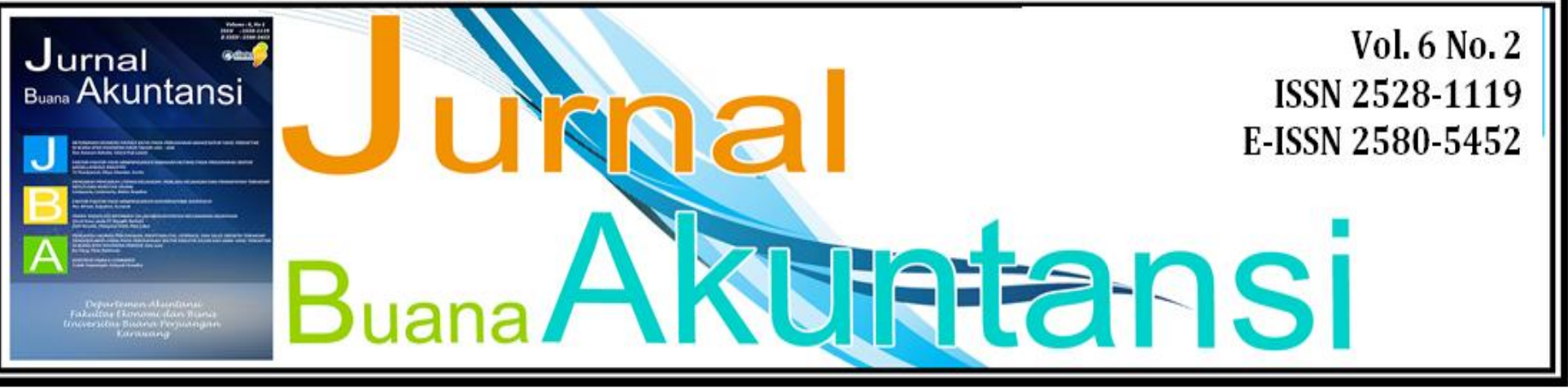

\title{
Inisiatif Lingkungan dan Tipe Manajemen Laba : Pengujian Terhadap Manajemen Laba Akrual dan Manajemen Laba Riil
}

\author{
Rosedian Andriani ${ }^{1}$, Andri Suherman ${ }^{2}$, Madadina Dwi Andini \\ 1,2,3Universitas Sultan Ageng Tirtayasa \\ 1rosedian.andriani@gmail.com
}

Penelitian ini bertujuan untuk menguji inisiatif lingkungan pada manajemen laba. Manajemen laba yang digunakan dalam penelitian ini adalah manajemen laba akrual dan manajemen laba riil. Manajemen laba akrual diproksikan dengan nilai absolut diskresioner akrual (Kothari) dan manajemen laba riil diproksikan dari penjumlahan nilai standar variabel CFO,PROD dan DISEXP. Inisiatif Lingkungan diukur melalui pengungkapan standar GRI 3.1, pengungkapan lingkungan sebagai indikator. Sampel yang digunakan adalah 80 perusahaan yang terdaftar di Bursa Efek Indonesia periode tahun 2010-2014, dengan menggunakan metode purposive sampling. Sampel kemudian dianalisis dengan menggunakan analisis regresi berganda. Hasil analisis ini menunjukkan bahwa inisiatif lingkungan tidak berpengaruh secara signifikan terhadap manajemen laba akrual. Selanjutnya, inisiatif lingkungan berpengaruh negatif terhadap manajemen laba riil.

Kata kunci : Inisiatif Lingkungan, manajemen Laba Akrual dan Manjemen Laba riil.

\section{Pendahuluan}

Standar akuntansi yang ditetapkan oleh Ikatan Akuntan Indonesia (IAI) mengizinkan pihak manajemen untuk mengambil suatu kebijakan dalam mengaplikasikan metode akuntansi guna menyampaikan informasi mengenai kinerja perusahaan kepada pihak ekstern. Pemberian fleksibilitas bagi manajemen untuk memilih satu dari seperangkat kebijakan akuntansi membuka peluang untuk perilaku oportunis dan kontrak efisien. Artinya, manajer yang rasional, akan memilih kebijakan akuntansi yang sesuai dengan kepentingannya. Dengan kata lain, manajer memilih kebijakan akuntansi yang dapat memaksimalkan expected utility-nya dan atau 
nilai pasar perusahaan. Perilaku oportunis dan kontrak efisien ini, mendorong manajer untuk melakukan manajemen laba (Januarsi, 2009).

Dalam Roychowdhury (2006) dijelaskan bahwa manajemen laba dapat dilakukan dengan manajemen laba akrual murni dan manajemen laba riil. Di Indonesia praktik manajemen laba masih marak terjadi terbukti dengan terungkapnya beberapa kasus mengenai manipulasi laba. Hal ini merugikan baik perusahaan maupun stakeholder karena tidak jarang perusahaan yang telah terungkap praktik manajemen laba mengalami kebangkrutan. Kasus yang terjadi pada tahun 2010 yang dilakukan oleh Bakrie Grup. Indonesia Coruption Watch (ICW) melaporkan dugaan manipulasi pelaporan penjualan tiga perusahaan tambang batu baramilik Grup Bakrie kepada Direktorat Jenderal Pajak. ICW menduga rekayasa pelaporan yang dilakukan PT Bumi Resources Tbk., dan anak usaha sejak 2003-2008 tersebut menyebabkan kerugian negara sebesar US\$ 620,49 juta. (Tempo, 2010).

Fenomena praktik kecurangan diyakini terjadi karena di latar belakangi oleh sistem pengelolaan yang masih rapuh pada badan usaha (Natalia dan Pudjo Laksono, 2013). Pengelolaan yang masih rapuh ini sebenarnya dapat diatasi dengan peningkatan transparansi perusahaan. Salah satu cara dalam peningkatan transparansi perusahaan adalah pengungkapan Corporate Social Responsibility (CSR). Pengungkapan lebih pada perusahaan dinilai akan memberikan pengawasan yang lebih bagi perusahaan sehingga perusahaan mengurangi praktik manajemen laba.

Kasus yang terjadi pada tahun 2010 yang dilakukan oleh Bakrie Grup. Indonesia Coruption Watch (ICW) melaporkan dugaan manipulasi pelaporan penjualan tiga perusahaan tambang batu baramilik Grup Bakrie kepada Direktorat Jenderal Pajak. ICW menduga rekayasa pelaporan yang dilakukan PT Bumi Resources Tbk., dan anak usaha sejak 2003-2008 tersebut menyebabkan kerugian negara sebesar US\$ 620,49 juta. Koordinator Divisi Monitoring dan Analisis Anggaran ICW, Firdaus Ilyas, mengatakan dugaan manipulasi laporan penjualan terjadi PT Kaltim Prima Coal (KPC), PT Arutmin Indonesia (Arutmin), dan induk kedua perusahaan tersebut, yakni PT Bumi Resources Tbk (Bumi). Hasil perhitungan ICW dengan menggunakan berbagai data primer termasuk laporan keuangan yang telah diaudit, menunjukkan laporan penjualan Bumi selama 2003-

2008 lebih rendah US\$ 1,06 miliar dari yang sebenarnya. Akibatnya, selama itu pula, diperkirakan kerugian negara dari kekurangan penerimaan Dana Hasil Produksi Batubara (royalti) sebesar US\$143,18juta. (Tempo, 2010).

Pada tahun 2013 juga terjadi kasus penggelapan di CV Buminet Prakarsa Jogja. Kasus penggelapan yang dilakukan oleh seorang karyawan asal Pacitan, Jawa Timur, YB, 29th, harus mendekam diruang tahanan Mapolsek Ngaglik, karena diduga menggelapkan uang perusahaan tempat ia bekerja sebesar Rp 149 juta. Informasi yang dihimpun HarianJogja.com, YB bekerja di CV Buminet Prakarsa Jogja yang beralamat 
di Sariharjo, Ngaglik, Sleman. Berdasarkan audit perusahaan, YB diduga menggelapkan uang perusahaan sebesar Rp 149 juta (Harianjogja, 2013).

Pengungkapan CSR menerima perhatian yang lebih dari regulator, pelaku pasar modal, masyarakat dan media (Social Investment Forum, 2012). Perusahaanperusahaan publik di Indonesia kini mulai melaksanakan CSR tersebut tentunya dengan berbagai inisiatif berbeda yang ditekankan. Di Indonesia, pelaksanaan CSR diatur dalam UU PT No. 40 tahun 2007 dan Undang-Undang No. 25 tahun 2007 tentang penanaman modal.Beberapa tahun sebelumnya, khususnya tahun 2010 hampir keseluruhan perusahaan terutama PT mengungkapkan laporan CSR pada annual report hal ini merupakan bukti perusahaan bertanggung jawab pada kepentingan stakeholder sesuai dengan konsep triple bottom line yaitu people, planet and profit (Lako, Andreas ; 2013). Motivasi manajemen perusahaan yang bertanggung jawab terhadap lingkungan dimungkinkan tidak mengejar pelaporan keuangan untuk kepentingan mereka sendiri karena akan membahayakan reputasi perusahaan dan mempertinggi litigasi. Beberapa literature terdahulu yang mendukung gagasan ini memiliki dampak pada kualitas laba yang dilaporkan lebih tinggi atau manajemen laba yang lebih rendah (DeFond dan Jimbalvo, 1991; Dechow et al., 1996; Rajgopal dan Venkatachalam,1997; Becker et al., 1998; Mitra, 2002; Knyazeva, 2007; Yu, 2008).

Pro dan kontra tentang implikasi implementasi CSR terhadap manajemen laba mendorong beberapa peneliti melakukan pengujian. Litt et al. (2014) melakukan penelitian mengenai efek inisiatif lingkungan terhadap manajemen laba. Penelitiannya tersebut menggunakan sampel 1460 perusahaan pada periode 1993-2010. Hasil penelitian tersebut menunjukkan bahwa inisiatif lingkungan berpengaruh negatif terhadap manajemen laba akrual. Hasil penelitian ini bertentangan dengan hasil penelitian Kim et al (2011) melakukan penelitian mengenai efek CSR terhadap manajemen laba akrual dan manajemen laba riil. Perusahaan yang berkontribusi terhadap CSR cenderung tidak mengelola laba melalui akrual diskresioner dan melalui aktivitas riil.

Tujuan Penelitian ini adalah untuk mengetahui apakah dengan adanya inisiatif lingkungan dapat mempengaruhi manajemen laba pada perusahaan terkait dengan alam yang terdaftar di Bursa Efek Indonesia. Manajemen laba dalam penelitian ini diukur melalui dua pengukuran yaitu manajemen laba akrual dan manajemen laba riil. Penelitian terdahulu (Petrovits, 2006; Prior et al., 2008; Hong et al., 2011) hanya berfokus pada pengaruh keseluruhan komponen kegiatan CSR (Corporate Social Responsibility) terhadap manajemen laba,akan tetapi masih jarang penelitian yang berfokus pada salah satu komponen CSR yaitu inisiatif lingkungan.

Penulis membatasi penelitian dengan komponen lingkungan dalam lingkup CSR dengan menguji bagaimana berbagai komponen terkait dengan manajemen laba. 
Inisiatif lingkungan merupakan salah satu komponen dari konsep tanggung jawab sosial pada perusahaan yang menerima pengawasan yang lebih dari stakeholder maupun pemerintah. Pengukuran yang digunakan dalam perhitungan inisiatif lingkungan menggunakan indeks GRI 2006. Tipe Industri yang diambil dalam penelitian ini adalah perusahaan yang berkaitan dengan alam dikarenakan perusahaan yang berkaitan dengan alam diprediksi akan memperkuat pengaruh antara variabel independen dan dependen dalam penelitian. Tipe industri dalam penelitian ini terdiri dari sektor pertanian dan pertambangan. Tahun tersebut 2010 dan 2014 dipilih karena pada tahun kebutuhan akan transparansi informasi mengenai inisatif lingkungan perusahaan yang terkait dengan alam mulai di perhitungkan di Indonesia setelah dikeluarkannya program PROPER di tahun 2010.

\section{Tinjauan Pustaka}

\subsection{Teori Agensi}

Agency theory mengambarkan model hubungan antara principal dan agent. Jensen and Meckling (1976) mendefinisikan hubungan keagenan sebagai kontrak yang terjadi ketika antara satu atau lebih individu (principal) mengikat perjanjian dengan individu lainnya (agent) yang melibatkan pendelegasian wewenang kepada agen dalam pembuatan keputusan. Pada perusahaan yang struktur modalnya dalam bentuk saham, pemegang saham bertindak sebagai prinsipal, dan dewan direksi sebagai agen mereka. Pemegang saham mempekerjakan para dewan direksi untuk bertindak sesuai dengan kepentingan prinsipal dalam hal ini adalah pemegang saham.

\subsection{Teori Stakeholder}

Stakeholder Theory diungkapkan oleh Freeman dalam buku "Strategic Management: Stakeholder Approach" tahun 1984 dikutip oleh Darrol J. Stanley (2007) dalam indriana (2009) menyatakan bahwa sukses suatu perusahaan tidak hanya tergantung pada kesuksesan manajemen dalam membangun hubungan dengan para pemegang saham tetapi juga ditentukan oleh kemampuan manjemen dalam membangun hubungan dengan stakeholder lainnya. Asumsi dasar stakeholder theory mnunjukkan bahwa perusahaan mempunyai kemampuan untuk mempengaruhi tidak hanya masyarakat secara umum tetapi juga stakeholder lainnya.

\subsection{Manajemen Laba}

Roychowdhury (2006), menyatakan bahwa manipulasi laba dapat dilakukan dengan cara manipulasi akrual murni atau dengan memanipulasi aktivitas riil. Manipulasi laba dengan manipulasi akrual murni merupakan manipulasi laba dengan discretionary accrual yang tidak memiliki pengaruh terhadap aliran kas secara langsung. Manipulasi laba akrual dilakukan pada akhir periode ketika manajer 
mengetahui laba sebelum direkayasa sehingga dapat mengetahui berapa besar manipulasi yang diperlukan agar target laba tercapai. Pada dasarnya, manipulasi laba akrual dibatasi oleh GAAP dan manipulasi ini dapat terdeteksi oleh auditor, investor maupun badan pemerintah sehingga dapat berdampak pada harga saham bahkan menyebabkan kebangkrutan atau kasus hukum. oleh karena itu, cara lain yang sering dilakukan oleh manjer untuk mengatur laba yaitu dengan manipulasi aktivitas riil (Wulandari dan Ayu, 2010).

\subsection{Inisiatif Lingkungan}

Lingkungan merupakan unsur penting bagi kemajuan perusahaan (Litt et al., 2014) Keberhasilan perusahaan dalam mengelola lingkungan hidup akan mempengaruhi kelangsungan hidup perusahaan di masa yang akan datang. Inisiatif Lingkungan merupakan bagian dari pengungkapan CSR (Litt et al., 2014). Beberapa hal yang diungkapkan dalam inisiatif lingkungan meliputi kegiatan perusahaan dalam kegiatannya mengelola lingkungan tempat perusahaan tersebut melakukan operasi perusahaannya.

\section{Pengembangan Hipotesis}

Pengaruh Inisiatif Lingkungan terhadap Manajemen Laba Akrual

Inisiatif lingkungan merupakan komponen dari pengungkapan CSR perusahaaan. Dalam pedoman GRI (Global Reporting Initiative) disebut tiga indikator dalam pengungkapan CSR. Tiga indikator tersebut meliputi indikator kinerja ekonomi, indikator kinerja lingkungan dan indikator kinerja sosial. Penelitian ini mengkaji indikator kinerja lingkuangan. Litt et al, dalam penelitiannya menyebutkan bahwa banyaknya indeks CSR yang diukur dapat menutupi pengaruh terhadap manajemen laba. Maka, dalam penelitian hanya menguji indikator lingkungan terhadap manajemen laba. Penelitian Litt et al (2014) menemukan bahwa terdapat pengaruh negatif antara inisiatif lingkungan dan manajemen laba akrual. Disamping itu, komponen lingkungan merupakan komponen yang sangat penting dan menentukan kelangsungan makhluk hidup lainnya.

\section{H1: Inisiatif Lingkungan berpengaruh negatif terhadap manajemen laba akrual}

\section{Pengaruh Inisiatif Lingkungan terhadap Manajemen Laba Riil}

Roychowdhury (2006) mengatakan bahwa Real-Earnings Management bukan merupakan pilihan yang tepat karena praktik tersebut akan mengakibatkan konsekuensi dalam jangka panjang yang berkaitan dengan aktivitas operasi perusahaan. Hal ini bertentangan tujuan perusahaan yaitu meningkatkan keberlangsungan perusahaan di daerah perusahaan beroperasi. Oleh karena itu, Hubungan baik antara perusahaan dan masyarakat di sekitarnya diharuskan tetap 
terjaga. Perusahaan yang menjalankan inisiatif lingkungan berusaha untuk memelihara hubungan jangka panjang dengan investor. Sehingga dalam hal ini, perusahaan yang berkontribusi terhadap inisiatif lingkungan akan berusaha untuk tidak melakukan manajemen laba yang justru akan merusak hubungan jangka panjang dengan investor.

H2: Inisiatif lingkungan berpengaruh negatif terhadap manajemen laba riil

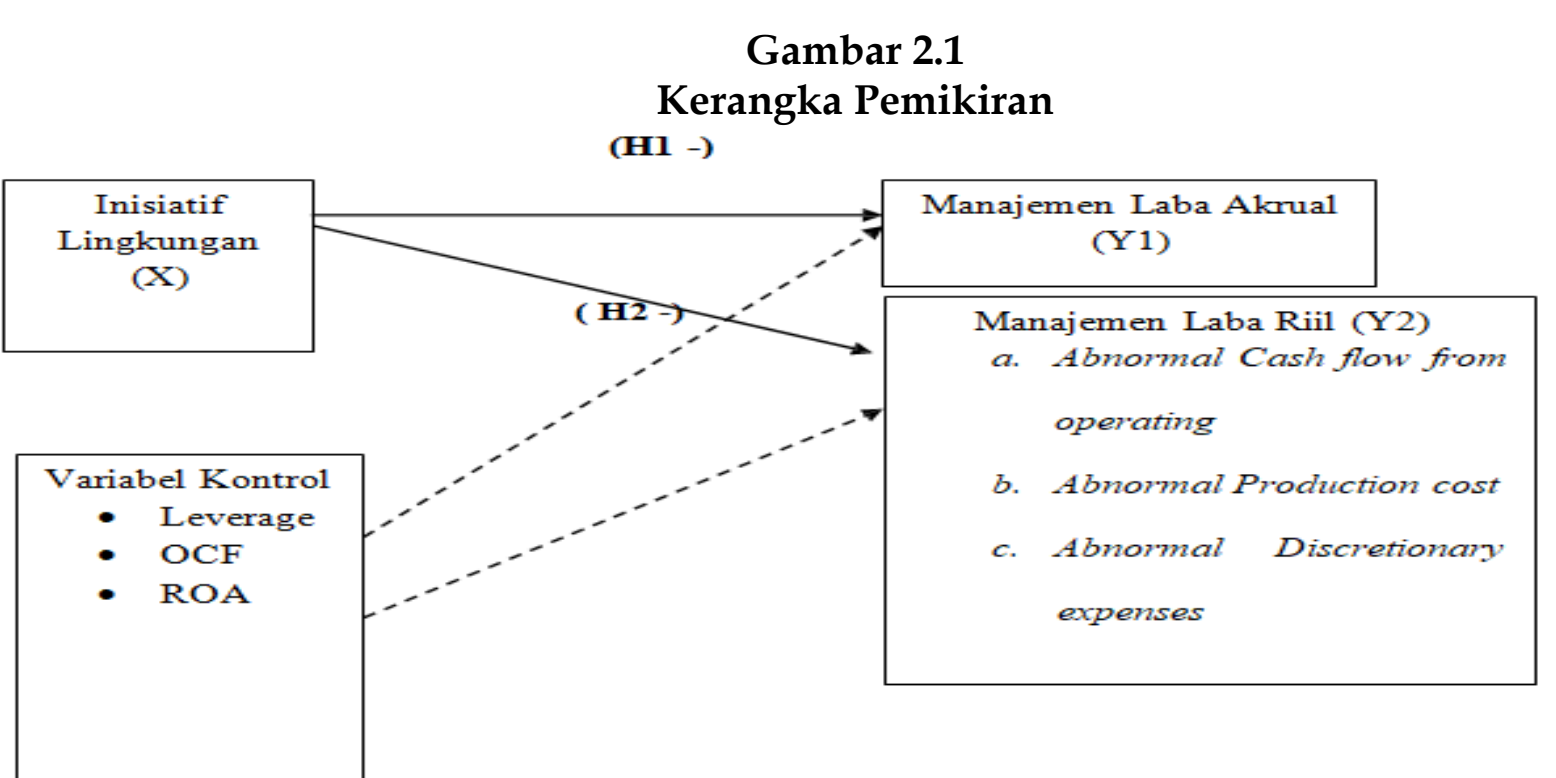

Sumber: Litt et al. (2014); Bardeschter (2011)

3. Metodologi Penelitian

Jenis data dalam penelitian ini adalah data dokumenter, yaitu data laporan keuangan, catatan atas laporan keuangan, dan laporan tahunan perusahaan yang terdaftar di Bursa Efek Indonesia (BEI) selain perbankan dan keuangan dari tahun 2010 sampai dengan tahun 2014.

Tabel 3.1

\section{Deskripsi Objek Penelitian}




\begin{tabular}{|l|l|}
\hline Keterangan & Jumlah \\
\hline $\begin{array}{l}\text { Perusahaan berkaitan dengan alam yang listing di BEI tahun } \\
\text { 2010-2014 }\end{array}$ & 24 \\
\hline Perusahaan yang delisting tahun 2010-2014 & 4 \\
\hline $\begin{array}{l}\text { Perusahaan yang tidak menerbitkan laporan keuangan dalam } \\
\text { satuan rupiah }\end{array}$ & 2 \\
\hline Perusahaan yang tidak menerbitkan laporan keuangan CSR & 2 \\
\hline Perusahaan yang dapat menjadi sampel & $\mathbf{1 6}$ \\
\hline Perusahaan yang menjadi sampel 2010-2014 (16 x 5) & $\mathbf{8 0}$ \\
\hline
\end{tabular}

Sumber: Data sekunder yang diolah, 2020

\section{Operasionalisasi Variabel}

Variabel dependen yang digunakan dalam penelitian ini adalah manajemen laba akrual dan manajemen laba riil. Untuk variabel dependen digunakan variabel inisiatif lingkungan. Variabel Dependen pertama yang digunakan dalam penelitian ini adalah manajemen laba akrual. Pengukuran manajemen laba akrual dengan menggunakan discretionary accruals sebagai proksi manipulasi laba dihitung dengan dengan model Kothari et.al (2005) adalah:

DAit $=$ TAit - NDAit

NDAit $=\alpha 0+\beta 1(1 /$ Assetsit-1 $)+\beta 2(\Delta$ REVit $)+\beta 3($ PPEit/At-1 $)+\beta 4($ ROAit/At-1 $)$ + e ........(2)

NDAit $=\alpha 0+\beta 1(1 /$ Assetsit-1 $)+\beta 2(\Delta$ REVit $)+\beta 3($ PPEit/At-1 $)+\beta 4($ ROAit/At-1 $)$ + e .... (3)

$\mathbf{D A}_{i t}=\mathbf{T A} A_{i t}-\mathbf{N D A}_{i t}$

$\mathrm{NI}_{\mathrm{it}} \quad=$ Net Income perusahaan i pada tahun $\mathrm{t}$

$\mathrm{CFO}_{\text {it }}=$ Aliran kas dari aktivitas operasi perusahaan i pada periode $\mathrm{t}$

$\mathrm{TA}_{\mathrm{it}} \quad=$ Total akrual perusahaan i pada tahun $\mathrm{t}$

$\triangle R E V_{i t}=$ Perubahan pendapatan perusahaan $\mathrm{i}$ tahun antara $\mathrm{t}$ dan $\mathrm{t}-1$

$\triangle \mathrm{REC}_{\mathrm{it}}=$ Perubahaan piutang $\mathrm{i}$ tahun antara $\mathrm{t}$ dan $\mathrm{t}-1$

$\mathrm{PPE}_{\mathrm{it}} \quad=$ Tingkat PPE perusahaan $\mathrm{i}$ pada tahun $\mathrm{t}$

$\mathrm{ROA}_{i \mathrm{t}}=\mathrm{ROA}$ perusahaan $\mathrm{i}$ pada tahun $\mathrm{t}$

$\mathrm{A}_{\mathrm{it}-1} \quad=$ Total aktiva perusahaan ipada akhir tahun $\mathrm{t}-1$

$\mathrm{NDA}_{\mathrm{it}}=$ Non discretionary accruals i pada tahun $\mathrm{t}$ 
Variabel independen yang selanjutnya adalah Real Earnings Management yang diproksi dengan abnormal cash flow from operating, abnormal production costs, dan abnormal discretionary expenses dengan menggunakan model Roychowdhury (2006).

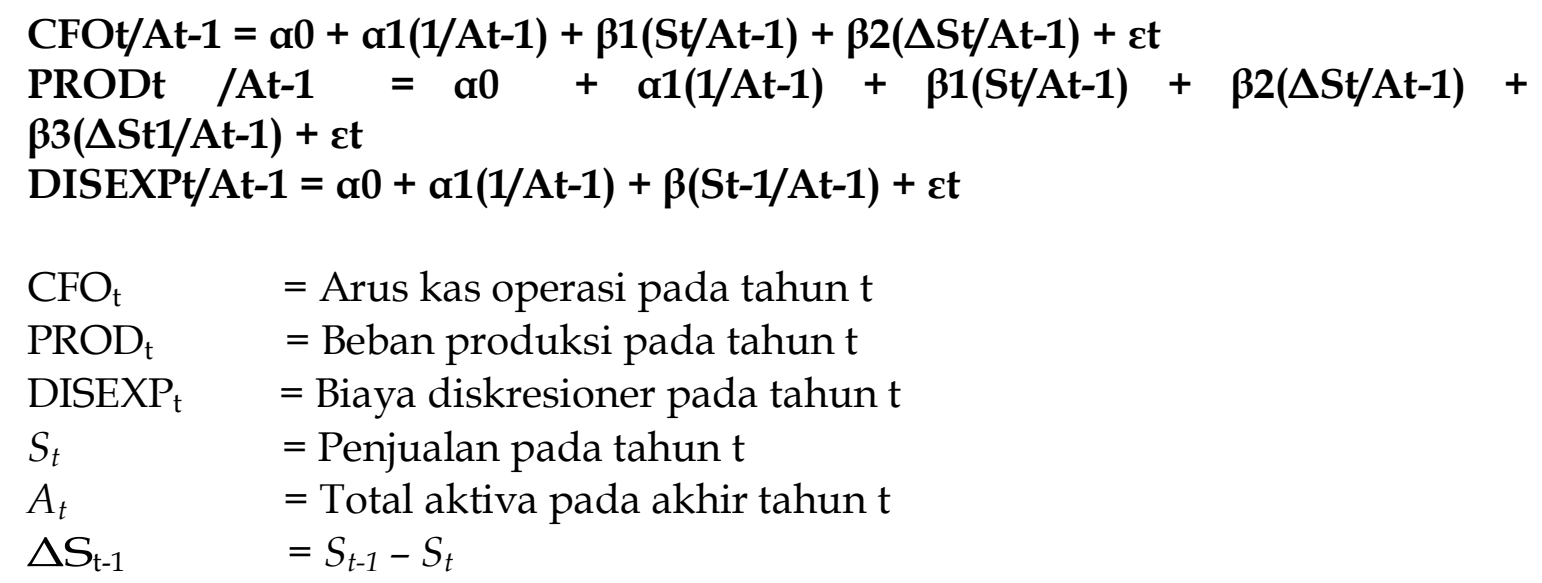

Dalam penelitian ini variabel inisiatif lingkungan akan diukur dengan menggunakan indeks GRI. Penelitian yang dilakukan oleh Barri litt (2014) menggunakan informasi dari database Kinder Lynderburg and Domini (KLD) sedangkan dalam penelitian ini menggunakan informasi dari database Global Reporting Initiative (GRI).

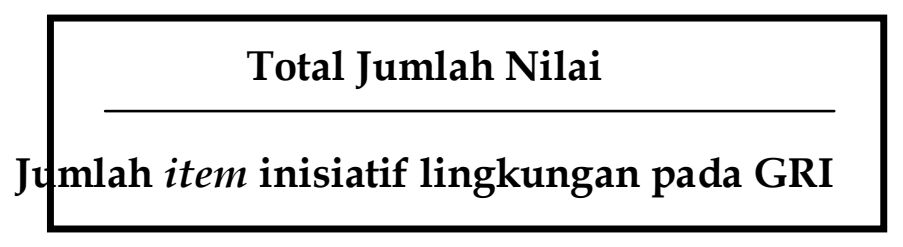

Variabel kontrol yang digunakan pada penelitian ini berdasarkan pada penelitian sebelumnya yang dilakukan oleh Litt et al (2014) yaitu, Leverage,, Operating Cash Flow, ROA.

\section{Analisis dan Pembahasan}

\subsection{Uji Normalitas}

Tabel 4.1 Hasil Uji Normalitas

\begin{tabular}{|c|c|c|}
\hline Model & Asymp. Sig. & Keterangan \\
\hline Model 1 & 0.169 & Berdistribusi normal \\
\hline Model 2 & 0.057 & Berdistribusi normal \\
\hline
\end{tabular}

Sumber: data sekunder yang diolah (2020) 
hasil uji Kolmogorov-Smirnov untuk model 1 menunjukkan nilai Asmpg. Sig 0,169 yang menunjukkan nilai residual berdistribusi secara normal. Model 2 dinyatakan berdistribusi normal dengan signifikansi sebesar 0,057. Karena nilai signifikansi dari kedua model diatas berada diatas 0,05 atau 5\%, maka dapat disimpulkan bahwa kedua model regresi berdistribusi secara normal.

\subsection{Uji Heteroskedastisitas}

Dalam penelitian ini, metode yang digunakan untuk mendeteksi ada atau tidaknya heteroskedastisitas dengan menggunakan Uji White.

\section{Tabel 4.3}

Hasil Uji Heteroskedastisitas - Uji White

\begin{tabular}{|l|c|c|c|c|}
\hline Model & $\mathbf{R}^{\mathbf{2}}$ & $\mathbf{c}^{\mathbf{2}}$ hitung & $\mathbf{c}^{\mathbf{2}}$ tabel & Keterangan \\
\hline Model 1 & 0,870 & 66,99 & 101,879 & $\begin{array}{c}\text { Tidak terjadi } \\
\text { heteroskedastisitas }\end{array}$ \\
\hline Model 2 & 0,081 & 26,29 & 73,31 & $\begin{array}{c}\text { Tidak terjadi } \\
\text { heteroskedastisitas }\end{array}$ \\
\hline
\end{tabular}

\section{Sumber: data sekunder yang diolah (2020)}

Pada model 1 tabel 4.16 didapatkan R2 sebesar 0.359 dan $\mathrm{c} 2=77 \times 0.870$ sehingga hasil c2 hitung adalah 66,99. Hasil ini lebih kecil daripada c2 tabel dengan $\mathrm{n}=77$ dan nilai signifikansi $5 \%$ yaitu sebesar 101,879. Hasil Uji White model 2 pada tabel 4.15 didapatkan hasil R2 sebesar 0.081 dan c2 $=55 \times 0.478$ sehingga hasil c2 hitung adalah 26.29. Hasil ini lebih kecil daripada c2 tabel dengan $\mathrm{n}=55$ dan nilai signifikansi 5\% yaitu sebesar 73,31.

\subsection{Uji Kebaikan Model (Goodness of Fit)}

\subsubsection{Uji Signifikansi Simultan (Uji Statistik F)}

Tabel 4.4

Hasil Uji Statistik F

\begin{tabular}{|l|l|l|}
\hline Model & F & Sig. \\
\hline
\end{tabular}




\begin{tabular}{|c|c|c|}
\hline Model 1 & 4,945 & 0.001 \\
\hline Model 2 & 4,576 & 0.003 \\
\hline
\end{tabular}

Sumber: data sekunder yang diolah (2020)

Pada tabel 4.4 didapat nilai F hitung untuk model regresi 1 sebesar 4,945 dengan probabilitas 0.001 . Karena probabilitas jauh lebih kecil dari 0.05 , maka model regresi 1 dapat digunakan untuk memprediksi manajemen laba di perusahaan yang terkait dengan alam atau dapat dikatakan bahwa variabel inisiatif lingkungan berpengaruh terhadap manajemen laba akrual.

Uji F model regresi 2 didapat nilai F hitung sebesar 4,576 dengan probabilitas 0.003 . Karena probabilitas yang juga jauh lebih kecil dari 0.05 maka model regresi 2 dapat digunakan untuk memprediksi manajemen laba riil di perusahaan yang terkait dengan alam dapat dikatakan bahwa variabel inisiatif lingkungan berpengaruh terhadap manajemen laba riil.

\subsection{Uji Hipotesis}

\subsubsection{Uji Hipotesis Model Persamaan Pertama}

\section{Tabel 4.6}

Hasil Analisis Regresi Berganda

\begin{tabular}{|c|c|c|c|c|c|c|}
\hline \multirow[b]{2}{*}{ Mod } & & \multicolumn{2}{|c|}{ Unstandardized Coefficients } & \multirow{2}{*}{$\begin{array}{c}\begin{array}{c}\text { Standardized } \\
\text { Coefficients }\end{array} \\
\text { Beta } \\
\end{array}$} & \multirow[b]{2}{*}{$t$} & \multirow[b]{2}{*}{ Sig. } \\
\hline & & $\mathrm{B}$ & Std. Error & & & \\
\hline \multirow[t]{5}{*}{1} & (Constant) &, 220 & 101 & & 2,178 &, 033 \\
\hline & ENV &, 002 &, 271 &, 001 &, 006 & ,995 \\
\hline & LEV & 203 &, 078 &, 297 & 2,605 &, 011 \\
\hline & skalaocf &, 071 &, 119 &, 066 &, 596 &, 553 \\
\hline & ROA &, 312 &, 088 &, 378 & 3,529 &, 001 \\
\hline
\end{tabular}

Sumber: data sekunder yang diolah (2016)

Berdasarkan hasil perhitungan diatas maka dapat diartikan bahwa variabel inisiatif lingkungan (ENV) memiliki arah koefisien positif 0,002 dengan tingkat signifikansi sebesar 0,995. Hasil ini diperkuat dengan hasil perhitungan thitung dan ttabel pada taraf signifikansi 5\% dan df (deg freedom) n-k $(77-5=72$ ) adalah 1,666. Hal ini dapat diinterpretasikan bahwa inisiatif lingkungan tidak berpengaruh terhadap manajemen laba akrual

\subsubsection{Uji Hipotesis Model Persamaan Kedua}

Tabel 4.7

Hasil Analisis Regresi Berganda 


\begin{tabular}{|c|c|c|c|c|c|c|}
\hline & & \multicolumn{5}{|c|}{ Coefficients $^{a}$} \\
\hline & & \multicolumn{2}{|c|}{ Unstandardized Coefficients } & \multirow{2}{*}{$\begin{array}{c}\begin{array}{c}\text { Standardized } \\
\text { Coefficients }\end{array} \\
\text { Beta }\end{array}$} & \multirow[b]{2}{*}{$t$} & \multirow[b]{2}{*}{ Sig. } \\
\hline \multicolumn{2}{|c|}{ Model } & $B$ & Std. Error & & & \\
\hline \multirow[t]{5}{*}{1} & (Constant) & .426 & 169 & & 2,529 & ,015 \\
\hline & sqri_ENV &,- 907 & .257 &,- 429 & $-3,529$ & ,001 \\
\hline & sqr_LEV & , 162 & 082 & .252 & 1,974 &, 054 \\
\hline & sqr_ocf & , 102 &, 075 & .232 & 1,367 & 178 \\
\hline & sqr_ROA &, 004 &, 043 & 016 & , 100 & 921 \\
\hline
\end{tabular}

a. Dependent Variable: REM

Sumber: data sekunder yang diolah (2020)

Berdasarkan hasil perhitungan diatas maka dapat diartikan bahwa variabel inisiatif lingkungan (Env) memiliki arah koefisien negatif -0.907 dengan tingkat signifikansi sebesar 0.001 .

\subsection{Pembahasan}

\subsubsection{Pengaruh Inisiatif Lingkungan terhadap Manajemen Laba Akrual}

Pengujian Hipotesis 1 dari penelitian ini adalah untuk menguji apakah inisiatif lingkungan yang diukur dengan perbandingan jumlah inisiatif lingkungan yang dilaporkan pada laporan keuangan dengan standar yang ditetapkan GRI (ENV) dapat manajemen laba akrual pada perusahaan yang terkait dengan alam. Berdasarkan hasil pengujian hipotesis 1 ini menghasilkan nilai koefisien $\beta 1$ sebesar 0,249 dengan signifikansi 0.995 ( $p>0.05$ ) Dengan kata lain hasil regresi menunjukkan bahwa inisiatif lingkungan berpengaruh positif dan tidak signifikan secara statistik terhadap manajemen laba akrual. Dalam hal persamaan penelitian ini mendukung penelitian Prior, dkk (2007) yang menyatakan bahwa manajemen laba berpengaruh positif dan signifikan terhadap tingkat CSR

\subsubsection{Pengaruh Inisiatif Lingkungan terhadap Manajemen Laba Riil}

Pengujian Hipotesis 2 dari penelitian ini adalah untuk menguji apakah inisiatif lingkungan yang diukur dengan perbandingan jumlah inisiatif lingkungan yang dilaporkan pada laporan keuangan dengan standar yang ditetapkan GRI (ENV) dapat manajemen laba riil pada perusahaan yang terkait dengan alam. Berdasarkan hasil pengujian hipotesis 2 ini menghasilkan nilai koefisien $\beta 1$ sebesar 0,907 dengan signifikansi -0.001 ( $p<0.05$ ) Karena $p$ value berada dibawah 0,05 maka hipotesis 2 berpengaruh negatif signifikan. Hal ini menunjukkan bahwa inisiatif lingkungan berpengaruh negatif terhadap manajemen laba riil, Hasil yang signifikan ini serupa dengan penelitian ini Kim et al (2012) yang menyatakan bahwa terdapat pengaruh positif CSR terhadap manajemen laba riil. 


\section{Kesimpulan, Keterbatasan, dan Saran 5.1 Kesimpulan}

Penelitian ini membahas tentang suatu model yang menguji pengaruh inisiatif lingkungan terhadap manajemen laba akrual dan manajemen laba riil pada perusahaan yang terkait dengan alam yang terdaftar di Bursa Efek Indonesia (BEI) melalui proksi perbandingan antara indeks lingkungan yang dilaporkan perusahaan dengan jumlah keseluruhan indeks melalui standar Global Reporting Index (GRI). Berikut kesimpulaan yang bisa ditarik dari hasil penelitian ini:

1. Berdasarkan pengujian regresi, diperoleh kesimpulan bahwa:

a. Inisiatif lingkungan tidak berpengaruh manajemen laba akrual. Hasil ini menunjukkan bahwa inisiatif lingkungan yang dilakukan perusahaan yang tergambar dari pengungkapannya pada laporan tahunan tidak mempengaruhi tingkat manajemen laba akrual yang dilakukan perusahaan. Hal ini dapat disebabkan masih sedikitnya indikator pengungkapan yang disajikan dalam laporan keuangan CSR perusahaan. Inisiatif ingkungan yang dilakukan perusahaan hanya digunakan untuk pemenuhan regulasi saja, dan masih belum adanya ketetapan berapa indeks yang harus dilaporkan perusahaan. Sebagian besar perusahaan melaporkan inisiatif lingkungan secara umum.

b. Inisatif lingkungan berpengaruh terhadap manajemen laba riil. Hasil ini menyatakan bahwa inisiatif lingkungan berpengaruh negatif terhadap manajemen laba riil. Hal ini menunjukkan inisiatif lingkungan mampu mengurangi praktik manajemen laba riil.

\subsection{Keterbatasan}

Dari hasil penelitian ini, peneliti menyadari bahwa masih banyak keterbatasanketerbatasan dalam penelitian ini, antara lain:

1. Penelitian ini tidak mempertimbangkan kejadian kejadian lain yang memiliki konsekuensi ekonomi.

2. Jumlah sampel ini kecil dibandingakan dengan penelitian terdahulu karena terbatas pada perusahaan yang terkait dengan alam yang terdaftar di Bursa Efek Indonesia.

3. Sampel perusahaan yang dijadikan objek penelitian hanya dua kategori dalam perusahaan manufaktur yaitu perusahaan pertanian dan pertambangan sehingga tidak dapat mencakup semua hasil temuan untuk seluruh perusahaan publik. 
4. Periode penelitian yang pendek yaitu 2010-2014 dengan hanya menggunakan 80 observasi.

\subsection{Saran}

Dari hasil penelitian yang telah dilakukan, dengan segala kerendahan hati peneliti bermasksud memberikan saran-ssaran yang dapat menjadi masukan bagi semua pihak, antara lain:

1. Bagi pihak regulator, diharapkan penelitian ini menjadi sinyal peringatan bagi pembuat kebijakan agar lebih mengawasi perusahaan dalam hal pelaporan keuangan sehingga tidak memberikan peluang bagi praktik manajemen laba akrual dan manajemen laba riil.

2. Bagi perusahaan, diharapkan dapat meningkatkan ketersediaan informasi agar lebih meningkatkan laporan keuangan, tidak terbatas pada laporan kinerja keuangan yang terlihat baik namun pelaporan inisiatif lingkungan ditingkatkan.

3. Bagi investor dan kreditur, diharapkan tidak hanya terfokus pada informasi laba saja karena adanya komponen akrual yang dapat diatur dengan pertimbangan manjer di akhir periode dan praktik manajemen laba riil selama aktivitas perusahaan berlangsung menggunakan pertimbangan manajer secara pribadi. Para investor dan kreditur perlu memperhatikan informasi non-keuangan yaitu pelaksanaan inisatif lingkungan di perusahaan pada pelaporan CSR dalam pengambilan keputusan.

4. Bagi peneliti selanjutnya, diharapkan:

a. Mempertimbangkan kejadian-kejadian yang memiliki konsekuensi ekonomi, seperti pada saat mengalami penurunan atau pertumbuhan ekonomi.

b. Sampel tidak terbatas pada industri manufaktur di pertanian dan pertambangan namun pada sektor lainnya misanya industry kimia dasar yang terdaftar di Bursa Efek Indonesia (BEI).

c. Memperluas periode penelitian agar hasil penelitian dapat diuji konsistensinya dan generalisasinya 


\section{Daftar Pustaka}

Becker, C.L., DeFond, M., Jiambalvo, J. and Subramanyam, K. 1998. “The effect of audit quality on earnings management", Contemporary Accounting Research, Vol. 15, pp. 1-22.

Dechow et.al. 1995. Dechow, P., R. Sloan, and A. Sweeney. 1996. Causes and consequences of earnings manipulation: An analysis of firms subject to enforcement actions by the SEC. Contemporary Accounting Research 13(1): 1-36.

DeFond, M. L. dan Jiambalvo, James. 1991. "Incidence and Circumstances of Accounting Errors". Accounting Review, Juli: 643-55.

Januarsi, Y. 2009. "Peran Kualitas Audit Dalam Mengurangi Managemen Laba Akrual dan Managemen Laba Real Pada Perioda Sebelum dan Setelah Kepmen Keuangan No. 423/KMK/09/2002". Tesis S2, Universitas Gadjah Mada.

Jensen., \& Meckling. 1976. Theory of the Firm: Managerial Behavior, Agency Costs and Ownership Structure. Journal of Financial Economics, 305-360.

Hong, Y., \& Andersen, M.L. 2011. The Relationship Between Corporate Social Responsibility and Earnings Management: An Explanatory Study. Journal of Business Ethics, 104:461-471.

http://www.tempo.co/read/news/2010/02/15/087225895/ICW-Ungkap- Manipulasi-PenjualanBatu-Bara-Grup-Bakrie

http://www.harianjogja.com/baca/2013/09/29/kasus-penggelapan-tilap-uang- perusahaanrp149-juta-karyawan-ditangkap-452046.

Ikatan Akuntan Indonesia. 2002. Standar Akuntansi Keuangan per 1 Oktober 2004, Penerbit Salemba Empat, Jakarta.

Indriana, Ina. 2009. Pengaruh Kinerja Sosial terhadap Kinerja Keuangan pada perusahaan BUMN. Tesis. Universitas Padjadjaran Bandung.

Kim, Y., Park, M.S. and Wier, B. 2012, "Is earnings quality associated with corporate social responsibility?", The Accounting Review, Vol. 87 No. 3, pp. 761-796.

Knyazeva, D. (2007), “Corporate governance, analyst following, and firm behavior”, working paper, New York University, New York, NY.

Litt, Barri. 2014, “Environmental Initiative and Earnings Management”, Journal of Managerial Auditing. Vol. 29 No. 1, 2014 pp. 76-106 
Mitra, S. (2002), “The impact of institutional stock ownership on a firm's earnings management practice: an empirical investigation", working paper, Louisiana State University, Baton Rouge, LA.

Natalia, Debby dan Eko Pudjo Laksono. 2013. Pengaruh Mekanisme Good Corporate Governance terhadap Praktik Earnings Management Badan Usaha Sektor Perbankan di BEI 2008-2011. Jurnal Ilmiah Mahasiswa Universitas Surabaya, Vol.2 No. 1.

Petrovits, C. 2006, "Corporate-sponsored foundations and earnings management", Journal of Accounting and Economics, Vol. 41 No. 3, pp. 335-361.

Prior, D., Surroca, J. and Tribo, J. 2008, “Are socially responsible managers really ethical? Exploring the relationship between earnings management and corporate social responsibility", Corporate Governance, Vol. 16 No. 3, pp. 160-177.

Rajgopal, S. and Venkatachalam, M. 1997. "The role of institutional investors in corporate governance: an empirical investigation”, working paper, Stanford University, Stanford, CA.

Roychowdhury .2006. Earnings management through real activities manipulation. Journal of Accountingand Economics 42 (3): 335-370

Social Investment Forum 2012, "Report on social responsible investing trends in the United States", available at: $\underline{\text { ww.socialinvest.org/areas/news/2012-trends.htm }}$

Wulandari, dan Ayu, Ratu. 2010. "Pengaruh Sistem Hukum terhadap Manajemen Laba dengan Kepemilikan Institusional sebagai Variabel Pemoderasi: Studi Perbandingan Inggris dan Perancis". Makalah disampaikan pada Simposium Nasional Akuntansi XII, Purwekerto

Yu, F. (2008), “Analyst coverage and earnings management”, Journal of Financial Economics, Vol. 88, pp. 245-271. 